\title{
READERS
Insight
}

Journal of Management Info (JMI)

ISSN:2313-3376

www.readersinsight.net/jmi

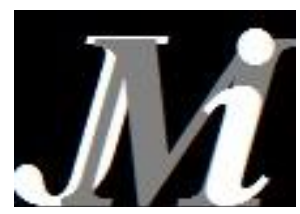

\section{Factors of job stress among university teachers in Pakistan: A conceptual review}

\author{
Anwar Khan¹, Rosman Bin Md Yusoffb² , Kamran Azam³ \\ 1 Integrity and Good Governance Research Group, Universiti Teknologi Malaysia, Malaysia \\ ${ }^{1}$ COMSATS Institute of I.T, Attock, Pakistan \\ ${ }^{2}$ Faculty of Management, Universiti Teknologi, Malaysia \\ ${ }^{3}$ Faculty of Management Sciences, Ripha Univeristy, Pakistan \\ * Corresponding author: akpashtoon1981@gmail.com
}

\begin{abstract}
University teaching is universally known for its stressful nature. The university teachers are exposed to various stressors at work as a result of which their working performance is affected. The current study has conceptually reviewed the different factors of Job Stress among university teachers in Pakistan by using non-systematic narrative review technique. Following review of existing literature, the findings of current study revealed nine potential factors as determinants of Job Stress among university teachers in Pakistan. These factors were related to both intra and extra organizational environments of universities in Pakistan. This study concludes that university teaching is a stressful profession in Pakistan. The problem of Job Stress should be managed both at individual and institutional levels. Individually the academic staff members should get awareness about causes and consequences of Job Stress. At institutional level the management of universities should provide Stress free conducive environment, so that university teachers could be saved from the devastating effects of Job Stress.
\end{abstract}

ARTICLE INFORMATION

\section{Received: 25 March 2018 \\ Revised: 25 May2018 \\ Accepted: 25 June 2018}

DOI:

http://dx.doi.org10.31580/jmi.v2i1.6

\section{Introduction}

Higher Education plays a very vital role the development of socio-economic system of a country, where the higher education institutions are strategic assets, which are continuously engaged fulfilling the human resource and technological needs of a country by providing updated technologies and skilled personnel. The responsibility of ensuring higher education is shared among the federal and provincial governments of Pakistan (Norric, 2006). At federal level it is governed by Ministry of Education and Higher Education Commission of Pakistan, while its institutional setup consists of universities, degree awarding institutions and affiliated colleges (WorldBank, 2007). To meet the human resources and technological needs of Pakistan, the Government of Pakistan has established total 154 universities throughout the country. The Government of Pakistan is encouraging its universities to engage in Research \& Development activities. For this purpose Government is aiming at establishing more universities, new departments within existing universities, technology parks and research centres, which can focus on the country's needs. Furthermore, Government has also approved different industrial research based projects for allowing the scientists to meet the technological requirements of country. In this whole process, the academic staff members working inside universities of Pakistan are exposed to certain unwanted factors, which emerged either from internal or external environments of the universities. These factors have negtaive effects on the physical and psychological health of academic staff members. Resultantly, the working performance and productivity of academic staff members is negatively affected. In order to comprehend the nature of these unwanted factors, the current study has done a non-systematic narrative review of related literature. Basically a narrative review of literature is less structured technique of searching information about any observable fact (Kumar, 2005). It is one of the most commonly used qualitative techniques that provide researchers autonomy in collecting information about any topic without any constraints (Ridenour, Benz, \& Newman, 2008). Following the review of literature, nine unwanted factors were identified as potential contributors of Job Stress among the academic staff members in Pakistan. These factors emerged from both internal as well as external environments of universities in Pakistan. The following section will discuss each of these factors in detail.

\section{Factors of job stress in Pakistan}

Following factors have been identified as potential contributors of Job Stress among the academic staff members in Pakistan:

\section{Social status of teacher in Pakistan}

The social setup of Pakistan believes in power. This land has been ruled by the British Colonial and the marks of which are still visible. The administrative services like Police, Military and Central Superior Services of Pakistan have both formal authority and social recognition, therefore they are enjoying higher social status as compared to that of teaching profession (Sheikh \& Iqbal, 2003). Therefore, the status of a teacher has remained like an individual with good qualification but having no formal power. Shah, Ali \& Khan 
(2012) found that Pakistani teachers are not satisfied with their social status. Such situations become a source of social stress, where the teachers think that there are not enough chances of upgrading their social status related with their profession (Humphrey, 2002).

\section{The problem of work overload}

Another issue is their workload. The academic staff members have to teach a diverse mix of four to six courses each semester, while the methodological and analytical bases of these courses are different. Apart from this, they are also engaged in research and university administration related activities. This creates work overload and role conflict among them as they have to work for long hours and remained engaged in so many activities. The problem of work overload is more severe in private sector universities/HEIs, because they give salaries and other benefits on the basis of amount of work assigned. Furthermore, they are also in cut throat competeition, becasue of which the employees are expetected to work more even in odd times. For this reason, Bhatti, Hashmi, Raza, Shaikh, \& Shafiq (2011) found work load and role conflict were major determients of Job Stress in universities of Paksitan.

\section{Demanding students and parents}

Each year large number students apply for admission to the different academic programs in both public and private universities/HEIs of Pakistan. The public sector universities/HEIs have low fees as compared to private sectors, furthermore the degree awarded by public sector universities/HEIs is given more worth. Therefore, each year a lot of students get enrolled in public sector universities/HEIs. The students which cannot get admission in the public sector universities/HEIs ultimately join private sector universities/HEIs. Dealing with a large number of diverse students in class becomes a big issue for the academic staff members. Apart from this, dealing of ever demanding parents also becomes a problem. This problem exists more in private sector universities/HEIs, where the parents claim that they have the right to demand because they paid large amount of fees for their children. Boyle, Borg, Falzon, \& Baglioni (1995) in their study on building a structure model for teacher's stress, mentioned that large size of class and liaison with parents are some of the major causes of stress among teachers.

\section{Job insecurity}

The academic staff members working in the different public and private sector universities/HEIs are often conscious about their job. In public sector the academic staff members having ad-hoc or contractual jobs are always worried about their job security. On the other side in private sector the jobs are purely temporary in nature and the academic staff members can lose job any point of time. The existing literature supports this fact, for example Sahibzada \& Bano (2012) conducted a study on Job Stress among faculty members in public and private sector universities of Pakistan. They found that those faculty members who had contractual jobs were more stressed due to fear of termination of job contract. Therefore, the job insecurity becomes a visible work stressor resultantly they cannot fully concentrate on their working performance.

\section{Ever changing educational policies}

Since 1947 , more than twenty two national educational policies and various higher education reforms have been introduced by Government of Pakistan (Shami, 2005), with the aim to improve the educational sector of Pakistan but unfortunately due to lack of proper mechanism, it has resulted in haphazard changes. These changes have affected the routine functioning of academic staff members, because new rules and procedures are sometime incompatible with the existing system. Thus, hampering the creativity and academic freedom (Yusoff, Khan, \& Azam, 2013).

\section{External political influence on universities}

The decision making process in the universities/HEIs of Pakistan is sometimes affected by the external political influence. Due to the corrupt political system of Pakistan, the political leaders, especially the top level elected political representatives play a significant and often dominated role in decision related to the appointments, transfers and promotions of academic and administrative staff. According to Bilal \& Khan (2012), corruption and politicization in universities in Pakistan is too much demoralizing for the academic staff members, as decisions are not done on merit basis. The ultimate result is development of frustration and stress among academic staff members.

\section{Problem of performance appraisal}

In the universities/HEIs of Pakistan, there is no proper performance evaluation system for academic staff members. The performance evaluation system is based on typical confidential reporting of performance after six months or one year time period, which lacks feedback mechanism, thus leaving academic staff members in darkness regarding their level of performance. Resultantly, the academic staff members constantly remain under pressure about the decisions related to their salary increment and promotion. Such situation is perceived stressful by the academic staff members and it adversely affects their organizational commitment and job satisfaction (Aziz, et al., 2013).

\section{Absence of training}

In the universities/HEIs of Pakistan, there is no proper system of training the academic staff members. Often academic staff members are hired as Lecturers or Research Assistants and then they are promoted on the basis of their length of service, up gradation of academic qualification, research publication, but during their routine job, they are not given proper training regarding the teaching. All this is mainly due to absence of specialized Human Resource Development offices in universities (Nasreen, 2012). Due to absence of a proper training system, most of them lack proper teaching and research skills; therefore their output and working efficiency is negatively affected, resultantly the pressure of fulfilling the Human Resources and technological needs of a country continue to exist. This pressure is experienced by academic staff members in terms of work overloads.

\section{Resource constraints}

The problem of resource constraints exist more in private sector universities, because their only source of revenue is fees collected from students. On the other side the public sector universities remain under resource constraint mainly due to red taped system of working, where official cases remained pending for long time and funds are released after long time, resultantly the Human Resources and materials in sufficiency prevails. In terms of less material resources, the administration of universities do not have budget for providing well maintained offices, transportation and research facilities. And in case of shortage of Human Resources the academic staff members have to perform an ever-increasing number of roles, which leads to role conflict and overload. Furthermore, the overall country is facing severe energy shortages due to which the physical working conditions of universities have been badly hampered. The academic staff members cannot work on computers for more than one hour. The heating and cooling arrangements are also not fully available due to such energy shortages (Khan, 2011).

\section{Conclusion}

Following the review of literature it was found that both internal as well as external factors contributed towards the development of Job Stress among academic staff in Pakistan. It is therefore concluded that university teaching is stressful profession in Pakistan, where academic staff members are exposed to wide variety of stressors, which hampers their routine working and social lives. It is thus suggested that the problem of Job Stress should be addressed at both individual and institutional levels in Pakistan. At individual level, the academic staff members should get enough awareness about the causes and consequences of Job Stress. It will be helpful in avoiding the causes of Job Stress. In this way the academic staff members can develop stress coping capacities with a passage of time to combat Job Stress. 
On the other side, at institutional level, the management of universities should provide a stress free conducive environment to the academic staff members. The universities should regularly launch stress management training programs, so that academic staff members can get awareness about Job Stress. Apart from universities, the policy makers in the higher education ministry of Pakistan should devise strategies for increasing the amount of financial resources allocated to the universities. The universities should be allowed to participate in policy formulating matters, so that both can comprehend the needs of universities in better way. In this manner the universities of Pakistan could be saved from overwhelming effects of Job Stress. Once the universities are safe then they can freely focus on the meeting the human resources and technological need of country.

\section{References}

Aziz, J., Saif, N., Qureshi, I., Rehman, K., ullah Khan, F., \& Khan, S. (2013) Relationship between Performance Appraisal Politics, Organizational Commitment and Turnover Intention. Public Policy and Administration Research, 3(5), 70-79.

Bhatti, N., Hashmi, M. A., Raza, S. A., Shaikh, F., \& Shafiq, K. (2011). Empirical Analysis of Job Stress on Job Satisfaction among University Teachers in Pakistan. International Business Research, 4(3), 264-270.

Bilal, M., \& Khan, I. (2012). Issues and prospects behind the depressed higher Education in Pakistan. Interdisciplinary journal of contemporary research in business, 4(7), 157-173.

Boyle, G., Borg, M., Falzon, J., \& Baglioni, A. (1995). A structural model of the dimensions of teacher stress. British Journal of Educational Psychology, 65(1), 49-67.
Humphrey, J. H. (2002). An anthology of stress: selected works of James H. Humphrey: Nova Science Publishers.

Khan, A. (2011). Pakistan: Universities must tackle national problems. University World News. Retrieved from http://www.universityworldnews.com/article.php?story=20111216171712 65

Nasreen, A. (2012). Faculty Training and Development in the Public Sector Universities of Punjab. International Journal of Business and Social Science, 3(3), 229-241.

Norric. (2006). Norric report on the System of Education in Pakistan: Nordic Recognition Information Centres, Denmark, Sweden.

Sahibzada, N., \& Bano, M. (2012). Occupational Role Stress among Public and Private University Teachers. PUTAJ Humanities and Social Sciences, 19, 29-40.

Shah, J., Ali, A., \& Khan, I. (2012). A Critical Appraisal of the Social Status of Teachers in Peshawar, Capital of Khyber Pakhtunkhwa, Pakistan. International Journal, 2(1), 176-186.

Shami, P. (2005). Education in Pakistan: policies and policy formulation: National Book Foundation, Ministry of Education.

Sheikh, M. A., \& Iqbal, M. Z. (2003). Status of teachers in Pakistan: UNESCO Office, Islamabad.

WorldBank. (2007). World Bank Report on Pakistan: Country Summary of Higher Education. Retrieved from http://siteresources.worldbank.org/EDUCATION/Resources/278200$1121703274255 / 1439264-$ 1193249163062/Pakistan_countrySummary.pdf.

Yusoff, R. B. M., Khan, A., \& Azam, K. (2013). Job Stress, Performance and Emotional Intelligence in Academia. Journal of Basic and Applied Science Resesearch, 3(6), 1-8. 